\title{
The Relationship between Privatization and Regulation on Foreign Investment Policies
}

\author{
Lihua Han1, Hikaru Ogawa² \\ ${ }^{1}$ School of Political Science and Public Administration, Shandong University, Jinan, China \\ ${ }^{2}$ School of Economics, Nagoya University, Nagoya, Japan \\ Email: lihuah@sdu.edu.cn, ogawa@soec.nagova-u.ac.jp
}

Received 23 January 2015; accepted 9 February 2015; published 12 February 2015

Copyright $(02015$ by authors and Scientific Research Publishing Inc.

This work is licensed under the Creative Commons Attribution International License (CC BY). http://creativecommons.org/licenses/by/4.0/

(c) (i) Open Access

\begin{abstract}
Using a simple mixed oligopoly model, this paper examines the relationship between marketopenings to foreign capital and privatization of a domestic public firm. Two types of marketopenings are considered. First is that, given the number of the firms, the restriction on the share of foreign capital in each corporate joint venture is relaxed. Second is that, given the share of foreign capital in each corporate joint venture, the restriction on the number of the firms is relaxed. The analysis shows that the optimal level of privatization critically depends on the types of market openings to foreign capital. The optimal level of privatization declines as the share of foreign capital in each corporate joint venture increases. By contrast, the optimal level of privatization rises with an increase in the number of the firms operating in the market. The two different strategies for market-openings result in the opposite impacts on the welfare-maximizing government's incentive for privatization.
\end{abstract}

Keywords

Regulation on Foreign Investment, Partial Privatization, Mixed Oligopoly

\section{Introduction}

The market-openings to foreign investors and the privatization of public firms have been among the most important items in reforming the economic structure of most developing countries (Smith and Trebilcock [1]). Some examples are China, India, Russia, and the so-called transition economies in Central and Eastern Europe, etc. Governments have adopted the policies of privatization of domestic public firms and open-door to foreign capital in these countries. The relationship between market-openings and privatization is not only concerned in the developing countries but also in the developed countries, particularly in the EU. Concerns over the changes 
in domestic industrial policies have arisen as new major players become outward investors, prompting a number of countries to review their privatization policies ${ }^{1}$.

The present paper attempts to analyze the optimal policy choice of government on privatization in the presence of the restriction on foreign capital ownership, by considering two types of mixed ownership. The first type is that a firm is jointly owned by the public sector and the domestic private sector. This type of firm is often called a semi- or partially-privatized public firm. The second type is that a firm is jointly owned by domestic and foreign private investors, which is called an international corporate joint venture. The former type of mixed ownership of public firm has been a feature of government policy in many developed and developing countries, and intensive studies have been conducted to examine the effects of partial privatization on the economic environment. Matsumura [3] is one of the eminent studies and develops a formal model for investigating the effect of partial privatization on social welfare in a domestic mixed oligopoly framework ${ }^{2}$. The latter type, which is the international corporate joint venture, has received little attention in previous mixed oligopoly studies. For instance, although Fjell and Pal [10] introduce foreign firms into mixed oligopoly, they only consider the situation that foreign investors own $100 \%$ ownership of a firm. Other articles on mixed oligopoly in an international context, such as Pal and White [11], Fjell and Heywood [12], Han [13], and Matsumura and Tomaru [14], have not analyzed the situation of the international corporate joint venture. The aim of this paper is to introduce foreign ownership into the model of mixed oligopoly.

This paper examines how the market-opening policy changes the optimal privatization policy. The analysis shows that the degree of privatization of a public firm critically depends on the level of restrictions on the market entry of foreign companies. As the restriction on the share of foreign ownership of domestic firms is relaxed so that the share of foreign capital in each joint venture increases, the government inhibits the privatization of public firm. In this sense, the market-opening policy may lead governments to pull back from their privatization programs. However, the market-opening policy, measured by the increase in the number of firms operating in the market, accelerates the privatization. The two different strategies for market-opening result in the opposite impacts on the government's incentive for privatization.

The remainder of the paper is organized as follows. We present the basic model in Section 2. Section 3 studies the market equilibrium. Section 4 concludes the paper.

\section{Model}

We consider a mixed oligopoly market, where there is a partially privatized public firm and $n$ identical private firms. These firms operate in a homogeneous good market with inverse demand given by $p=a-Q$, where $p$ is market price and $Q \equiv q_{0}+q_{1}+\cdots+q_{n}$ is the total quantity of the output in the market. $q_{j}(j=0,1, \cdots, n)$ is the output of firm $j$. Firm 0 is a (public) firm which maximizes a certain objective function given later. Firm $i=1, \cdots, n$ is a profit maximizing private firm, which is partially owned by foreign investors. The cost function is identical for all firms and is given by $C_{j}=F+q_{j}^{2} / 2$ where $F$ is the fixed cost ${ }^{3}$. We assume $F=0$ since we do not consider the entry problem.

The profit of firm $j(j=0,1, \cdots, n)$ is given by

$$
\pi_{j}=(a-Q) q_{j}-q_{j}^{2} / 2 .
$$

Public firm 0 is owned by the government, so that its profit, $\pi_{0}$, will be involved in the social welfare. Similarly, if private firm $i \quad(i=1, \cdots, n)$ is the domestic firm, its profit, $\pi_{i}$, should be involved in the social welfare. However, $\pi_{i}$ will be eliminated from social welfare if firm $i$ is owned by foreign investors. In this paper, we define social welfare as

\footnotetext{
${ }^{1}$ With the background of increase in the degree of free-trade within the EU, Barcena-Ruiz and Garzon [2] state that "the competitive environment created with the implementation of the single market has led member states to take stock of the benefits they obtain by holding on to state ownership in some companies".

${ }^{2}$ See Fershtman [4], Bennett and Maw [5], Gupta [6], Sun, Zhang and Li [7], Chao and Yu [8], and Kumar and Saha [9] for the literature on partial privatization in the mixed oligopoly models.

${ }^{3}$ We use a quadratic cost function following the standard mixed oligopoly model (see studies such as Fjell and Pal [10], De Fraja and Delbono [15], White [16], and Du, Heywood and Ye [17]). In our model, the public and private firms hold identical productive technology. When public and private firms hold identical productive technology, under constant and decreasing marginal costs, social welfare is maximized with one public firm that monopolizes the entire market. In order to focus on active mixed oligopoly markets, the assumption of increasing marginal costs is made.
} 


$$
W=C S+\pi_{0}+\sum_{i=1}^{n}\left(1-\alpha_{i}\right) \pi_{i}
$$

where $C S \equiv Q^{2} / 2$ is the consumer surplus. In (2), $\alpha_{i}\left(0 \leq \alpha_{i} \leq 1\right)$ represents the status of regulation on foreign ownership of domestic private firms, and $\alpha_{i}=0 \quad\left(\alpha_{i}=1\right)$ represents the status in which (full) foreign ownership is prohibited (allowed). In this paper, the restrictions on foreign capital ownership (investment) are represented by $\alpha$, where $\alpha_{i}=\alpha \quad \forall i$ since we assume identical private firms. When $\alpha=0$, foreign capital ownership are not allowed so that private firms are owned by domestic residents/consumers. $\alpha=1$ corresponds to the case in which firm $i$ is a foreign enterprise which is completely owned by foreign investors. If $\alpha$ is positive (but not equal to one), private firms are considered as a joint ownership enterprise. In this case, it is natural to consider that $100(1-\alpha)$ percent of firm $i$ 's profit should be attributed to domestic residents. This assumption follows Huizinga and Nielsen [18] and Ogawa and Sanjo [19], and is well-justified, when the interest is the effects on the equilibrium values of an exogenous change in $\alpha$. In consideration of a foreign capital ownership, we can examine how the abolition of control on the foreign investment targeted by an external institution such as the WTO changes the privatization policy.

The government owns a share of $(1-\theta) \in[0,1]$ of the public firm. The manager of this firm will maximize the weighted average of social welfare and the profit. Following Matsumura [3], we define the objective function of firm 0 as

$$
V=\theta \pi_{0}+(1-\theta) W
$$

Note that the manager of fully privatized firm $(\theta=1)$ seeks the firm's profit, while the manager of a fully nationalized firm $(\theta=0)$ maximizes social welfare.

\section{Equilibrium}

The stages of the game involved are as follows:

Stage 1: The government maximizes (2) to decide the level of privatization, $\theta$;

Stage 2: Observing $\theta$, the firms simultaneously and independently choose their outputs. Private firm $i$ maximizes (1) and public firm 0 maximizes (3).

To obtain the sub-game perfect Nash equilibrium, we solve the game by standard backward induction method. That is, the equilibrium values are deduced subsequently from the last stage to the first stage.

\subsection{Second Stage}

For given $\theta$, the standard Cournot-Nash equilibrium in the second stage can be derived as

$$
\begin{gathered}
q_{0}=a[n \alpha(1-\theta)+2] / \Delta, \\
q_{i}=a(\theta+1) / \Delta, \\
p=2 a(\theta+1) / \Delta,
\end{gathered}
$$

where $\Delta \equiv n \alpha(1-\theta)+(2+n) \theta+n+4>0$. Comparative statics results yield

$$
\begin{gathered}
\partial q_{0} / \partial \theta=-2 a(n \alpha+1)(n+2) / \Delta^{2}<0 \\
\partial q_{i} / \partial \theta=2 a(n \alpha+1) / \Delta^{2}>0 \\
\partial p / \partial \theta=4 a(n \alpha+1) / \Delta^{2}>0
\end{gathered}
$$

Hence, the privatization decreases firm 0's output, and increases firm $i$ 's output and the market price. Using (4) and (5), the profits and consumer surplus in the second stage can be obtained as

$$
\pi_{0}=\frac{a^{2}[n \alpha(1-\theta)+2][4 \theta+2-n \alpha(1-\theta)]}{2 \Delta^{2}},
$$




$$
\begin{gathered}
\pi_{i}=\frac{3 a^{2}(\theta+1)^{2}}{2 \Delta^{2}}, \\
C S=\frac{a^{2}[n \alpha(1-\theta)+n(1+\theta)+2]^{2}}{2 \Delta^{2}} .
\end{gathered}
$$

Notice that while firm $i$ 's profit is always positive, the profit of firm 0 is negative (positive) if $4 \theta+2-n \alpha(1-\theta)<(>) 0^{4}$. Furthermore, from (10) to (12), we have

$$
\begin{gathered}
\partial \pi_{i} / \partial \theta=6 a^{2}(\theta+1)(n \alpha+1) / \Delta^{3}>0 \\
\partial \pi_{0} / \partial \theta=2 a^{2}(n \alpha+1)\left[\left(n^{2} \alpha+4 n \alpha+4\right)(1-\theta)-2 n \theta\right] / \Delta^{3} .
\end{gathered}
$$

(13) and (14) show that while privatization serves to increase firm $i$ 's profit, its effect on the firm 0's profit is ambiguous. Furthermore, the following comparative statics result shows that the privatization results in a negative effect on the consumer surplus:

$$
\partial C S / \partial \theta=-4 a^{2}(n \alpha+1)[n \alpha(1-\theta)+n(1+\theta)+2] / \Delta^{3}<0 .
$$

\subsection{First Stage}

In the first stage, the government chooses the level of privatization of public firm 0. Substituting (10)-(12) into (2), the objective function of the government in the first stage is obtained as

$$
W=\frac{a^{2}(\theta+1)\left\{n^{2}[1+\theta+2 \alpha(1-\theta)]+n[3 \theta+\alpha+7(1-\alpha \theta)]+8\right\}}{2 \Delta^{2}} .
$$

The maximization of (16) with respect to $\theta$ yields

$$
\partial W / \partial \theta=-2 a^{2}(n \alpha+1)\left[\theta\left(n^{2} \alpha+5 n \alpha+n+4\right)-n(1-\alpha+n \alpha)\right] / \Delta^{3} .
$$

Setting $\partial W / \partial \theta=0$, we obtain the optimal degree of privatization as ${ }^{5}$

$$
\theta=\frac{n(1-\alpha+n \alpha)}{n^{2} \alpha+5 n \alpha+n+4} .
$$

From (18), we have the main results of this paper.

Proposition 1. Privatization is set back with the relaxation of the regulation on foreign capital ownership; $\partial \theta / \partial \alpha<0$.

Proof. From (18), we have

$$
\frac{\partial \theta}{\partial \alpha}=\frac{-2 n(n+2)}{\left(n^{2} \alpha+5 n \alpha+n+4\right)^{2}}<0 .
$$

For any $n \geq 1$ and $0 \leq \alpha \leq 1, \partial \theta / \partial \alpha<0$.

Proposition 1 shows that the market-opening policy measured by the increases in the share of foreign capital ownership in private firm gives the government less incentive to privatize its own public firms. This is simply because if a private firm is domestically owned, its profit remains in the country. This provides the government with an incentive to privatize public firm. By contrast, if foreign capitalists own private firms, private firm profits flow out to foreign countries, so that public firm decreases the degree of privatization so as not to yield profits to private firms and to keep their profits in the country.

${ }^{4}$ Lump-sum transfer from consumer to firm 0 may be conducted when $\pi_{0}$ takes a negative value.

${ }^{5}$ We can easily confirm that $\theta$ is in $[0,1]$ for $n \geq 1$ and $0 \leq \alpha \leq 1$, and the second-order condition is satisfied,

$$
\begin{aligned}
\partial^{2} W / \partial \theta^{2}= & -4 a^{2}(n \alpha+1)\left\{n^{3} \alpha(2-\alpha-\theta+\alpha \theta)+n^{2}\left[(4+5 \theta) \alpha^{2}+(1+5 \alpha)(1-\theta)+(1-\alpha \theta)\right]\right. \\
& +n[(7-6 \theta)+3 \alpha(3-2 \theta)]+8(1-\theta)\} / \Delta^{4}<0 .
\end{aligned}
$$


Proposition 2. Privatization is promoted by an increase in the number of firms operating in the market; $\partial \theta / \partial n>0$.

Proof. From (18), we have

$$
\frac{\partial \theta}{\partial n}=\frac{2[n \alpha(3 n \alpha+4)+2(1-\alpha)]}{\left(n^{2} \alpha+5 n \alpha+n+4\right)^{2}}>0 .
$$

For any $n \geq 1$ and $0 \leq \alpha \leq 1, \partial \theta / \partial n>0$.

Proposition 2 indicates that the market-opening policy measured by the increase in the number of private firms gives the government more incentive to privatize its own public firms. The intuition behind Proposition 2 is as follows. The increase in the number of private firms enhances the consumer surplus and the social welfare while it results in the decline in the profits of the private firms ${ }^{6}$. Under this circumstance, the optimal level of privatization decreases.

\section{Concluding Remarks}

In this paper, we investigated the effects of market-openings policies on the degree of privatization in the mixed oligopoly market. A series of mixed oligopoly analyses indicate that the existence of foreign investment considerably changes the equilibrium outcome. Nevertheless, market-openings strategies in the mixed market model with partial privatization have been nearly neglected. By introducing a change in the levels of regulation on foreign capital ownership, we have shown alternative features of the degree of privatization in mixed market.

We first show that the relaxation of restriction on foreign capital ownership sets back privatization of public firm. Second, with the increase in the number of private firms that are jointly owned by domestic and foreign investors, the government increases the degree of privatization. In this sense, while the market-opening policies called for by international agreement, such as WTO, tend to set back the privatization of public firm, the increase in the number of firms operating in the market accelerates the privatization. The two different strategies for market-openings result in the opposite impacts on the government's incentive for privatization.

Finally, it should be noted that the qualitative results of this analysis are like to hold true, even though we relax some of our assumptions such as allowing asymmetric cost functions among the public firm and the private firms. Nonetheless, it seems to be useful to investigate the relationship between privatization and regulation on foreign investment considering general demand and cost functions, which is a limitation of this paper. Furthermore, since our interest is the exogenous change in the regulation of foreign investment, we simply assume that the government only controls the degree of privatization. However, the government may use the level of foreign investment regulation as policy variables. The extension of the present model to the one that considers the endogenous determination of foreign investment regulation and privatization could well provide insightful implications on the optimal policies taken in the mixed oligopoly market. These are left for a future research.

\section{Acknowledgements}

The authors thank the anonymous referee for the valuable comments. The first author has been supported by grants from the planning fund of humanity and social science research of Ministry of Education (No. 13YJA790030) and the independent innovation foundation of Shandong University (No. IFW12112).

\section{References}

[1] Smith, D.A.C. and Trebilcock, J.M. (2001) State-Owned Enterprises in Less Developed Countries: Privatization and Alternative Reform Strategies. European Journal of Law and Economics, 12, 217-252. http://dx.doi.org/10.1023/A:1012817825552

[2] Barcena-Ruiz, J.C. and Garzon, M.B. (2005) International Trade and Strategic Privatization. Review of Development Economics, 9, 502-513. http://dx.doi.org/10.1111/j.1467-9361.2005.00290.x

\footnotetext{
${ }^{6}$ It is readily verifiable that $\partial C S / \partial n=2 a^{2}(1+\theta)(1+\alpha+\theta-\alpha \theta)[2+n(1+\alpha+\theta-\alpha \theta)] / \Delta^{3}>0$, $\partial W / \partial n=a^{2}(1+\theta)\left[\left(12+n+n \alpha+10 \theta+6 \theta^{2}\right)(1-\alpha)+n \alpha^{2} \theta(8-7 \theta)+8 \alpha\left(n-\theta^{2}\right)+n \theta(2+\theta+2 \alpha+2 \alpha \theta)\right] / 2 \Delta^{3}>0$ and $\partial \pi_{i} / \partial n=-3 a^{2}(1+\theta)^{2}(1+\alpha+\theta-\alpha \theta) / \Delta^{3}<0$.
} 
[3] Matsumura, T. (1998) Partial Privatization in Mixed Duopoly. Journal of Public Economics, 70, 473-483. http://dx.doi.org/10.1016/S0047-2727(98)00051-6

[4] Fershtman, C. (1990) The Interdependence between Ownership Status and Market Structure: the Case of Privatization. Economica, 57, 319-328. http://dx.doi.org/10.2307/2554937

[5] Bennett, J. and Maw, J. (2003) Privatization, Partial State Ownership, and Competition. Journal of Comparative Economics, 31, 58-74. http://dx.doi.org/10.1016/S0147-5967(02)00008-2

[6] Gupta, N. (2005) Partial Privatization and Firm Performance. Journal of Finance, 60, 987-1015. http://dx.doi.org/10.1111/j.1540-6261.2005.00753.x

[7] Sun, Q., Zhang, A. and Li, J. (2005) A Study of Optimal State Shares in Mixed Oligopoly: Implications for SOE Reform and Foreign Competition. China Economic Review, 16, 1-27. http://dx.doi.org/10.1016/j.chieco.2004.06.009

[8] Chao, C.C. and Yu, E.S.H. (2006) Partial Privatization, Foreign Competition, and Optimum Tariff. Review of International Economics, 14, 87-92. http://dx.doi.org/10.1111/j.1467-9396.2006.00562.x

[9] Kumar, A. and Saha, B. (2008) Spatial Competition in a Mixed Duopoly with One Partially Nationalized Firm. Journal of Comparative Economics, 36, 326-341. http://dx.doi.org/10.1016/j.jce.2007.03.001

[10] Fjell, K. and Pal, D. (1996) A Mixed Oligopoly in the Presence of Foreign Private Firms. Canadian Journal of Economics, 29, 737-743. http://dx.doi.org/10.2307/136260

[11] Pal, D. and White, M.D. (1998) Mixed Oligopoly, Privatization, and Strategic Trade Policy. Southern Economic Journal, 65, 264-281. http://dx.doi.org/10.2307/1060667

[12] Fjell, K. and Heywood, J.S. (2002) Public Stackelberg Leadership in a Mixed Oligopoly with Foreign Firms. Australian Economic Papers, 41, 267-281. http://dx.doi.org/10.1111/1467-8454.00164

[13] Han, L. (2012) Strategic Privatization and Trade Policies in an International Mixed Oligopoly. The Manchester School, 80, 580-602. http://dx.doi.org/10.1111/j.1467-9957.2011.02245.x

[14] Matsumura, T. and Tomaru, Y. (2012) Market Structure and Privatization Policy under International Competition. Japanese Economic Review, 63, 244-258. http://dx.doi.org/10.1111/j.1468-5876.2012.00572.x

[15] De Fraja, G. and Delbono, F. (1989) Alternative Strategies of a Public Enterprise in Oligopoly. Oxford Economic Papers, 41, 302-311.

[16] White, M.D. (1996) Mixed Oligopoly, Privatization and Subsidization. Economics Letters, 53, 189-195. http://dx.doi.org/10.1016/S0165-1765(96)00916-0

[17] Du, N.H., Heywood, J.S. and Ye, G.L. (2013) Strategic Delegation in an Experimental Mixed Duopoly. Journal of Economic Behavior \& Organization, 87, 91-100. http://dx.doi.org/10.1016/j.jebo.2013.01.006

[18] Huizinga, H. and Nielsen, S.B. (1997) Capital Income and Profit Taxation with Foreign Ownership of Firms. Journal of International Economics, 42, 149-165. http://dx.doi.org/10.1016/S0022-1996(96)01449-3

[19] Ogawa, H. and Sanjo, Y. (2007) Location of Public Firm in the Presence of Multinational Firm: A Mixed Duopoly Approach. Australian Economic Papers, 46, 191-203. http://dx.doi.org/10.1111/j.1467-8454.2007.00313.x 
Scientific Research Publishing (SCIRP) is one of the largest Open Access journal publishers. It is currently publishing more than 200 open access, online, peer-reviewed journals covering a wide range of academic disciplines. SCIRP serves the worldwide academic communities and contributes to the progress and application of science with its publication.

Other selected journals from SCIRP are listed as below. Submit your manuscript to us via either submit@scirp.org or Online Submission Portal.
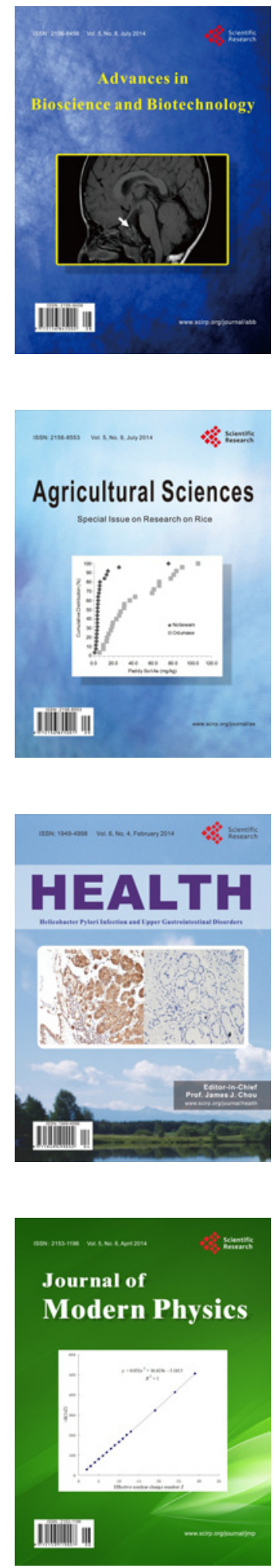
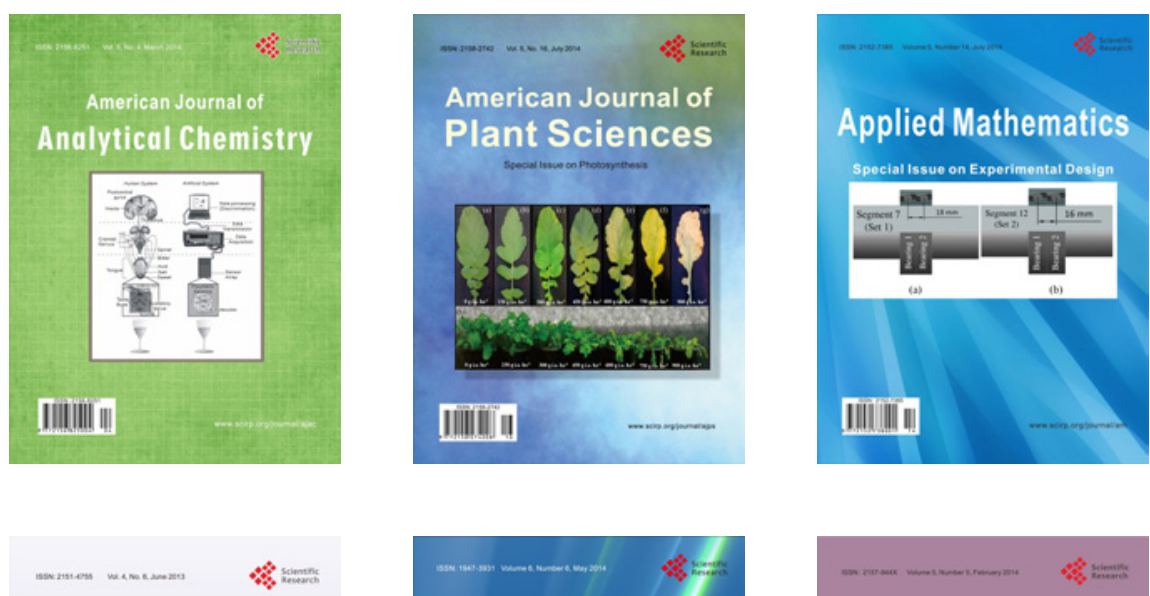

Creative Education
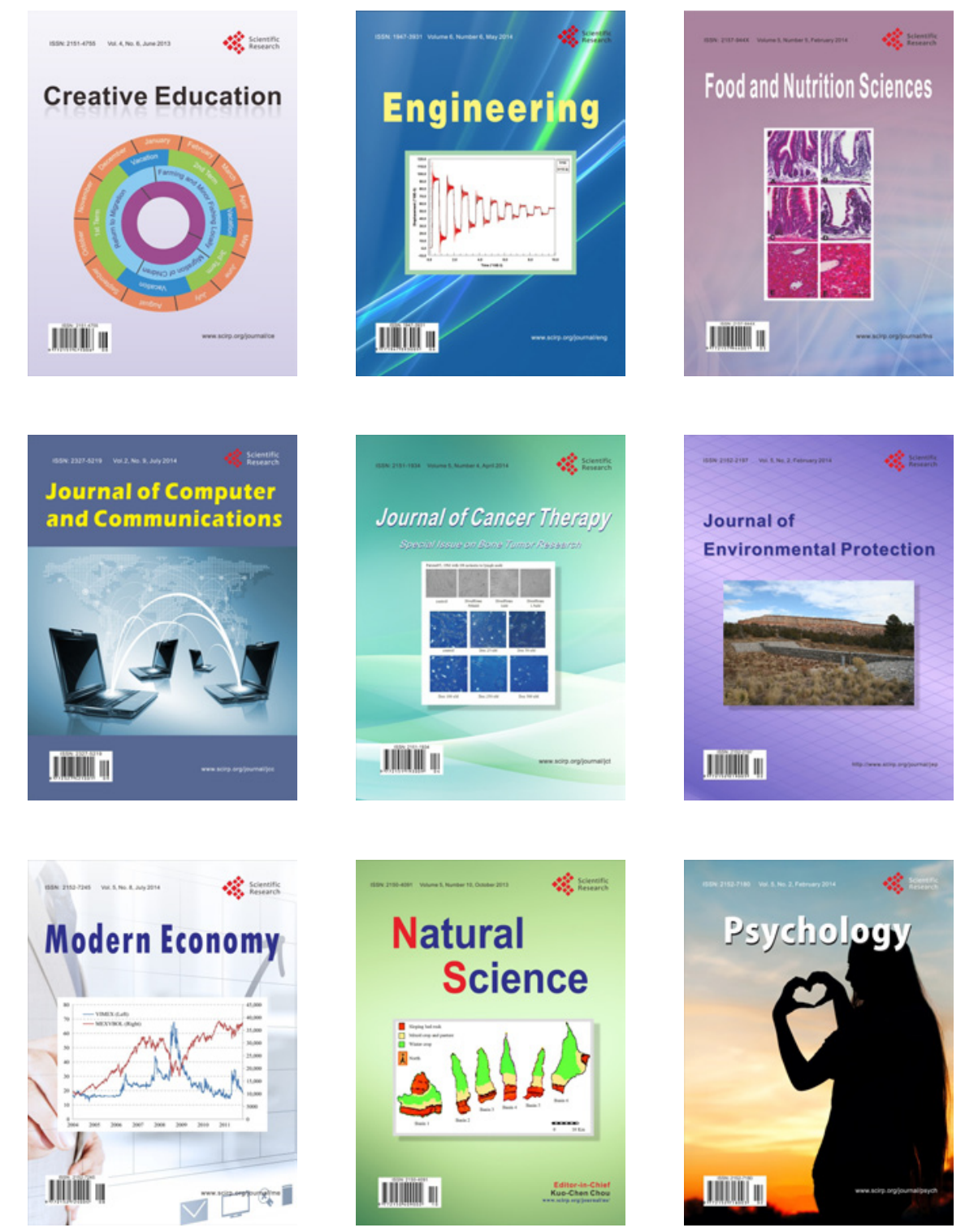